\title{
The Influence of HIF-1 $\alpha$ Expression on Apoptosis and Number of T Lymphocyte in Peyer's Patches after Burn with Delayed Fluid Resuscitation in Rats at Plateau
}

\author{
Cheng Zhang1*, Yi Liu1, Ming Ma1, Shifan Zhang2 \\ ${ }^{1}$ Department of Burns and Plastic Surgery, Lanzhou General Hospital, Lanzhou, China \\ ${ }^{2}$ Department of Thoracic Surgery, Lanzhou General Hospital, Lanzhou, China \\ Email: ^zc5976@yahoo.com, xmgt2288212@sina.com, zhang1929@tom.com
}

How to cite this paper: Zhang, C., Liu, Y., Ma, M. and Zhang, S.F. (2016) The Influence of HIF-1 $\alpha$ Expression on Apoptosis and Number of $\mathrm{T}$ Lymphocyte in Peyer's Patches after Burn with Delayed Fluid Resuscitation in Rats at Plateau. Surgical Science, 7, 390-399.

http://dx.doi.org/10.4236/ss.2016.79056

Received: March 29, 2016

Accepted: September 9, 2016

Published: September 13, 2016

Copyright $\odot 2016$ by authors and Scientific Research Publishing Inc. This work is licensed under the Creative Commons Attribution International License (CC BY 4.0).

http://creativecommons.org/licenses/by/4.0/

(c) (i) Open Access

\begin{abstract}
Objective: To research the expression of hypoxia inducible factor-1 alpha (HIF-1 alpha) on the apoptosis and number of T lymphocyte in Peyer's patches after severe burn on plateau in rats. Methods: Wistar rats $(n=130)$ were subjected to deep thickness burn injury (30\% TBSA, III degree), at two different altitudes. 60 of them were given delayed fluid resuscitation (DFR, $\mathrm{n}=30$ at each altitude) $6 \mathrm{~h}$ after burn at different altitude; 60 of them were carried out immediate fluid resuscitation (IFR, $\mathrm{n}=$ 30 at each altitude); 10 rats were subjected to $37^{\circ} \mathrm{C}$ warm water as sham burn (SG, $\mathrm{n}$ =10). The Peyer's patches were harvested from the ileum of rats at different time point after burn respectively. The expression of HIF-1 alpha, CD3(+) and the apoptosis and number of T lymphocyte in Peyer's patches were detected by tissue microarray technology and immunohistochemistry. Results: The apoptosis was higher in DFR group than that in IFR group. The increase in HIF-1 alpha expression was observed mainly on cell nucleus in T lymphocytes. The expression levels of HIF-1 alpha in Peyer's patches were much higher in DFR group and IFR group than those in SG, and they were higher at high altitude (3848 metres) than those at lower altitude (1517 metres), and also higher in DFR group compared with IFR group (all $P<0.05$ ). The expression levels of $\mathrm{CD}^{+}$in Peyer's patches were much lower in DFR group and IFR group than those in sham group, and the lowest value appeared at 12 hours after burn (all $P<0.05$ ). Conclusion: High expression of HIF-1 alpha may induce the apoptosis of T lymphocytes in Peyer's patches after severe burn with delayed fluid resuscitation in rats at plateau.
\end{abstract}

\section{Keywords}

Delayed Fluid Resuscitation, Peyer's Patches, Apoptosis, HIF-1 $\alpha$, Burn, Plateau 


\section{Introduction}

Hypoxia is a well-known cause of cell injury at plain, with important pathological implications in many disease processes, including cerebral ischemia and myocardial infarction [1]. Cells in hypoxia expressed a variety of adaptive or death gene products to satisfy altered metabolic demands or to remove irreversibly damaged cells [2]. However, in the case of severe hypoxic damage beyond the cell's adaptive capability, deathpromoting genes are expressed, resulting in necrosis or apoptosis [3].

Hypoxia-inducible factor- $1 \alpha$ (HIF- $1 \alpha$ ), as a kind of transcriptional factor, is known to play a fundamental role in adaptive or death process in response to hypoxia [4], it is induced, stabilized, and translocated to the nucleus to regulate the transcription of a variety of genes involved in adaptive responses, such as increased $\mathrm{O}_{2}$ delivery and angiogenesis [5]. Our previous study and other's have demonstrated that the apoptosis rate of gut-associated lymphatic tissue (GALT) increased postburn (PB) with delayed resuscitation [6]-[8], but the mechanism remained controversial. It was reported that CD3positive human $\mathrm{T}$ cells accumulating in inflammatory tissue and expressing HIF- $1 \alpha$, indicating a role of hypoxia-mediated signals in regulation of $\mathrm{T}$ cell function. Surprisingly, accumulation of HIF- $1 \alpha$ in human T cells required hypoxia but also TCR/CD3mediated activation [9]. As the marker of $\mathrm{T}$ lymphocyte, $\mathrm{CD}^{+}$molecule expressed on the surface of matured Tymphocytes. The $\mathrm{CD}^{+}$molecule could stabilize the structure of $\mathrm{CD}^{+}-\mathrm{T}$ cell antigen receptor (CD3-TCR) and transfer the signals of activation. There was no report about the effects of HIF- $1 \alpha$ expression on the apoptosis and proliferation of T lymphocytes in Peyer's patches PB at plateau. In this study, a burn model with delayed resuscitation was duplicated at sub-plateau (1517 $\mathrm{m}$ above sea level) and plateau (3848 m above sea level) and the effects of HIF-1 $\alpha$ expression on the lymphocytes in Peyer's patch was observed.

\section{Material and Method}

\subsection{Animal Model}

Total of 132 Wistar rats were supplied by medical experimental animal center of Gansu Chinese Traditional Medical College. The average weight was $200 \pm 30$ g. Half of them were female. Animal was kept in single cage under $19^{\circ} \mathrm{C}-25^{\circ} \mathrm{C}$ for 1 week before injury. They were fasted $12 \mathrm{~h}$ before experiment. Animals were anesthetized with an injection of pentobarbital sodium $(40 \mathrm{mg} / \mathrm{kg})$. The back of the rats was shaved before experiment and was immersed into $90^{\circ} \mathrm{C}$ hot water for $20 \mathrm{~s}$ to produce a $30 \%$ total body surface area (TBSA) scald burn on the back of the rats at $1517 \mathrm{~m}$ and $3848 \mathrm{~m}$ above sea level. The experiment at $1517 \mathrm{~m}$ altitude was carried out in the animal experimental center of Lanzhou General Hospital in Lanzhou city, Gansu province. The experiment at $3848 \mathrm{~m}$ altitude was carried out in an animal experimental base of high altitude medicine in Mahanshan mountain in Yuzhong county, Gansu province, China. Animals were transported from Lanzhou (1517 $\mathrm{m}$ above sea level) to Mahanshan mountain ( $3848 \mathrm{~m}$ above sea level) in 1 day and the experiment was started after 3 days acclimation, finished in 10 days. All animals were randomly divided into 6 groups by table of 
random digit: immediate fluid resuscitation group (IFR, $\mathrm{n}=30$ at each altitude, the animals received saline injection intraperitoneally according to the Parkland formula immediately after injury for resuscitation, $40 \mathrm{ml} / \mathrm{kg}$ body weight); delayed fluid resuscitation group ( DFR, $\mathrm{n}=30$ at each altitude, the same amount of fluid was given $6 \mathrm{~h}$ PB; and sham group (SG, $n=6$ at each altitude, the back of the animals were immersed into $37^{\circ} \mathrm{C}$ warm water for $20 \mathrm{~s}$ to imitate scald burn without saline injection).

\subsection{Sample Harvesting}

At 6, 12, 24, 48 and 72 hours $\mathrm{PB}$, animals ( $\mathrm{n}=6$, at every time point in each group) were euthanized after being anesthetized with intraperitoneal injection of pentobarbital sodium $(40 \mathrm{mg} / \mathrm{kg})$. All the Peyer's patches in the intestine $(10 \mathrm{~cm}$ distal to the ileocecal junction) were harvested and were immediately fixed in $10 \%$ neutral buffered formalin. The samples in sham group were harvested 6 hours after sham burn.

\subsection{Histopathological Observation of Peyer's Patches}

The Peyer's patches were then embedded in parafin and sectioned. After stained with hematoxylin and eosin, histopathological observation and photographing were carried out under optical microscope.

\subsection{The Detection of Lymphocyte Apoptosis in Peyer's Patches}

The terminal deoxynucleotidyl transferase (TdT)-mediated d-UDP-biotin nick end labeling (TUNEL) method was used to detect the apoptosis of lymphocytes in Peyer's patches with modification [10], using the cell death kit (Roche Company). After DAB coloration and hematoxylin counterstain, they were observed and photographed under microscope. The cell number in 6 high power fields (more than 1000 cells) were counted and the positive cells were identified. The apoptotic percentage was counted as following:

Apoptosis percentage $=$ positive cell number $/$ counted cell number $\times 100 \%$

\subsection{The Detection of Expression of HIF-1 $\alpha$ and CD3+ by Immunohistological Method}

The expression of HIF- $1 \alpha$ and $\mathrm{CD}^{+}$protein from the Peyer's patches were determined by Strept-Actividin-Biotin-Complex (SABC) method. The paraffin sections $(4 \mu \mathrm{m})$ were dehydrated in xylene and graded ethanol series, and added in order with primary antibody [HIF-1 $\alpha$ (rabbit polyclonal antibody, Wuhan Boster Co., China), CD3 ${ }^{+}$(rabbit anti-rat monoclonal antibody, Wuhan Boster Co.)], after incubated in a humid box overnight, biotinylated secondary antibody (rabbit anti-rat IgG, Wuhan Boster Co.) added and incubated for $20 \mathrm{~min}$ at $37^{\circ} \mathrm{C}, \mathrm{SABC}$ reagents and $\mathrm{DAB}$ solution (Wuhan Boster Co.) added. For negative control, the sections were treated with PBS instead of primary antibody. Immunohistological quantitative analysis was carried out as following: ten sample sections from each group were chosen for analysis. 6 high power visual fields were observed randomly. The Dpcontrollor 7.0 photographing system and the 
pro-plus 5.0/Ipp5.0 Image analysis system were used to determine the absorbance (A value) of HIF- $1 \alpha$ and $\mathrm{CD}^{+}$protein.

\subsection{Statistical Analysis}

Results are expressed as means \pm s. Group comparisons were carried out by variance analysis, using SPSS 10.0 medical statistical software. $P$-value less than 0.05 was considered significant.

\section{Result}

\subsection{Result of Histopathological Observation of Peyer's Patches}

The construction of Peyer's patches in SG at $1517 \mathrm{~m}$ was very clear. There was no inflammatory cell infiltration. The construction of Peyer's patches was also clear in IFR group, only some germinal center of some follicle enlarged. There was light inflammatory cell infiltration $6-12 \mathrm{~h}$ PB. Inflammatory cell infiltration was observed in DFR group, apoptotic lymphocytes distributed in the germinal center singularly or areataly. The pathological changes aggravated gradually after 6 - $12 \mathrm{~h}$ PB.

The construction of Peyer's patches in SG at 3848m was clear too, but both the B cell zone and $\mathrm{T}$ cell zone enlarged and the volume of Peyer's patches increased too. There was a little inflammatory cell infiltration in IFR group, single apoptotic cell distributed in the germinal center, the membrane of apoptotic cell shrinked, the neuclous karypyknosis and margination of chromatin and round and ellipse apoptotic body were observed. The above pathological changes alleviated 48 - $72 \mathrm{~h} \mathrm{~PB}$.

\subsection{Immunohistochemistry Observation of Apoptotic Cell and Apoptosis Rate Change at Different Time Point (Table 1)}

Apoptotic cells were observed in Peyer's patches at two altitudes in experimental groups. The apoptotic cell number increased gradually 6 - $12 \mathrm{~h} \mathrm{~PB}$ and reached the zenith at $12 \mathrm{~h}$ PB. The nucleus of apoptotic cell showed brown color, the chromosome condensed, and distributed in the germinal center of Peyer's patches clusterly (Figure $1)$.

Table 1. Comparison of lymphocyte apoptosis rate in Peyer's patches in burned rats at two altitudes (ap\%, $\bar{x} \pm \mathrm{s})$.

\begin{tabular}{ccccc}
\hline altitude & group & $6 \mathrm{~h} \mathrm{~PB}$ & $12 \mathrm{~h} \mathrm{~PB}$ & $24 \mathrm{~h} \mathrm{~PB}$ \\
\hline \multirow{3}{*}{$1517 \mathrm{~m}$} & SG $(\mathbf{n}=\mathbf{6})$ & $11.36 \pm 2.1$ & & \\
& IFR $(\mathbf{n}=\mathbf{1 8})$ & $15.92 \pm 0.52^{\mathrm{a}}$ & $19.47 \pm 0.63^{\mathrm{a}}$ & $17.52 \pm 0.34^{\mathrm{a}}$ \\
& DFR $(\mathbf{n}=\mathbf{1 8})$ & $20.09 \pm 0.81^{\mathrm{ab}}$ & $25.68 \pm 1.26^{\mathrm{ab}}$ & $21.43 \pm 0.70^{\mathrm{ab}}$ \\
& SG $(\mathbf{n}=\mathbf{6})$ & $14.28 \pm 0.88^{\mathrm{c}}$ & & \\
\multirow{3}{*}{$\mathbf{3 8 4 8} \mathrm{m}$} & IFR $(\mathbf{n}=\mathbf{1 8})$ & $17.92 \pm 0.76^{\mathrm{ac}}$ & $24.42 \pm 1.51^{\mathrm{ac}}$ & $21.73 \pm 0.78^{\mathrm{ac}}$ \\
& DFR $(\mathbf{n}=\mathbf{1 8})$ & $24.06 \pm 1.33^{\mathrm{abc}}$ & $28.90 \pm 1.91^{\mathrm{abc}}$ & $27.17 \pm 1.56^{\mathrm{abc}}$ \\
\hline
\end{tabular}

Notice: a: $v s$ SG at the same altitude, $P<0.05$; b: $v s$ IFR at the same altitude, $P<0.05$; c: $v s$ corresponding group at low altitude, $P<0.05$; Blank means no data. 


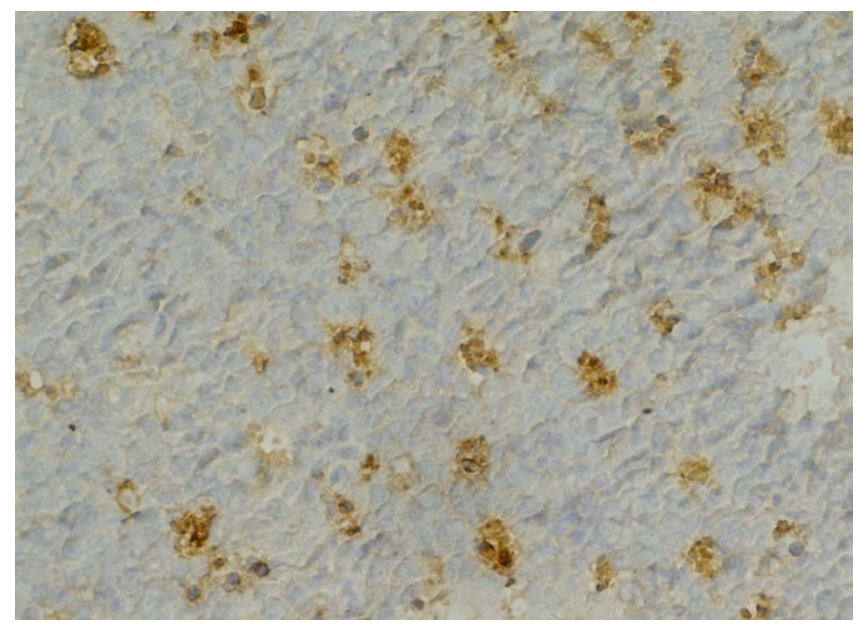

Figure 1. A lot of Tunel positive apoptotic lymphocytes were discerned in the germinal center of Peyer's patch $12 \mathrm{~h}$ PB in IFR group at $3848 \mathrm{~m}$ altitude. The apoptotic lymphocytes showed deep brown color. TUNEL $\times 400$.

Quantitative analysis of lymphocyte apoptosis rate after 6 - $24 \mathrm{~h}$ PB showed: 1) the apoptosis rate in DFR group was higher than that in IFR group at the same altitude 6 $24 \mathrm{~h} \mathrm{~PB}(P<0.05)$. The highest apoptotic rate in experimental group was at $12 \mathrm{~h} \mathrm{~PB}(P$ $<0.05)$. 2) The apoptosis rate in both DFR and IFR group at high altitude was higher than that in low altitude $(P<0.05)$ (Table 1$)$.

\subsection{The Change of HIF-1 $\alpha$ Expression in Every Group at Different Altitude (Table 2)}

The HIF-1 $\alpha$ expression increased both in IFR and DFR group at $6-72 \mathrm{~h} \mathrm{~PB}$, compared with that in SG at the same altitude. The positive expression mainly distributed in the nucleus of lymphocytes, showing a buffy colour granules (Figure 2). The HIF-1 $\alpha$ expression in DFR and IFR group at every time point at different altitude were higher than that in SG $(P<0.05$ all). The expression of HIF- $1 \alpha$ at $6 \mathrm{~h}, 24 \mathrm{~h}, 72 \mathrm{~h}$ PB in DFR group at low altitude, at $6 \mathrm{~h}, 12 \mathrm{~h}, 24 \mathrm{~h}, 48 \mathrm{~h}$ PB in DFR at high altitude were higher than that in IFR group $(P<0.05)$. The HIF-1 $\alpha$ expression in DFR group at $6 \mathrm{~h}, 12 \mathrm{~h}, 24$ $\mathrm{h}, 48 \mathrm{~h} \mathrm{~PB}$ at high altitude were higher than that in groups at low altitude $(P<0.05)$.

\subsection{The Change of $\mathrm{CD}^{+}$Expression at Different Altitude (Table 3)}

Compared with the $\mathrm{CD}^{+}$expression at the same altitude in $\mathrm{SG}$, the $\mathrm{CD}^{+}$expression decreased both in IFR and DFR groups, mainly distributed on the cell membrane of T lymphocyte, showing brow-yellow color. The quantitative analysis showed that the $\mathrm{CD}^{+}$expressions at both altitudes in DFR and IFR groups at different time point were lower than that in SG (P value all less than 0.05 ). The $\mathrm{CD}^{+}$expressions in DFR group at low altitude and in DFR group at $6 \mathrm{~h}, 12 \mathrm{~h}, 24 \mathrm{~h}, 48 \mathrm{~h}, 72 \mathrm{~h} \mathrm{~PB}$ at high altitude were all lower than that in IFR group at the same altitude. The $\mathrm{CD}^{+}$expressions both in DFR and IFR groups from $6 \mathrm{~h}$ to $72 \mathrm{~h} \mathrm{~PB}$ were all lower than that in corresponding low altitude groups $(P<0.05)$. 


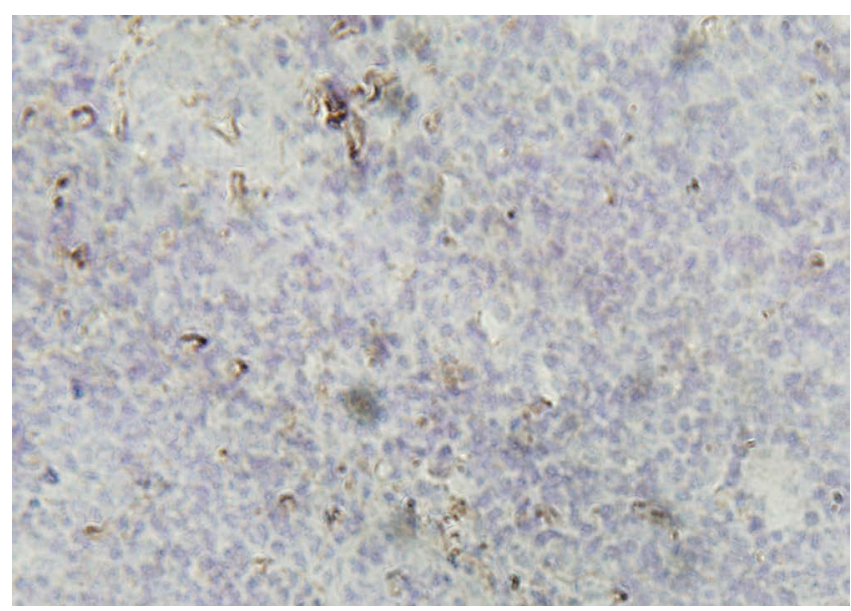

Figure 2. An amount of HIF-1a positive lymphocytes appeared in the paracortical area of the Peyer's patch $12 \mathrm{~h} \mathrm{~PB}$ at $3848 \mathrm{~m}$ in DFR group, and the cells of positive expression showed brown color. SABC $\times 400$.

Table 2. The HIF-1 $\alpha$ expression in Peyer's patch at two altitudes (A value $\bar{x} \pm \mathrm{s}$ ).

\begin{tabular}{|c|c|c|c|c|c|c|}
\hline altitude & group & $6 \mathrm{~h} \mathrm{~PB}$ & $12 \mathrm{~h}$ PB & $24 \mathrm{~h}$ PB & $48 \mathrm{~h}$ PB & 72 h PB \\
\hline \multirow{3}{*}{$1517 \mathrm{~m}$} & $S G(n=6)$ & $0.133 \pm 0.016$ & & & & \\
\hline & IFR $(n=30)$ & $0.159 \pm 0.005$ & $0.195 \pm 0.006^{\mathrm{a}}$ & $0.175 \pm 0.003^{\mathrm{a}}$ & $0.168 \pm 0.007^{\mathrm{a}}$ & $0.155 \pm 0.003^{\mathrm{a}}$ \\
\hline & DFR $(n=30)$ & $0.201 \pm 0.008^{\mathrm{ab}}$ & $0.257 \pm 0.013^{\mathrm{a}}$ & $0.214 \pm 0.007^{\mathrm{ab}}$ & $0.208 \pm 0.006^{\mathrm{a}}$ & $0.222 \pm 0.008^{\mathrm{ab}}$ \\
\hline \multirow{3}{*}{$3848 \mathrm{~m}$} & $S G(n=6)$ & $0.166 \pm 0.009$ & & & & \\
\hline & IFR $(n=30)$ & $0.179 \pm 0.008^{\mathrm{ac}}$ & $0.244 \pm 0.015^{\mathrm{ac}}$ & $0.217 \pm 0.008^{\mathrm{ac}}$ & $0.206 \pm 0.008^{\mathrm{ac}}$ & $0.187 \pm 0.007^{\mathrm{ac}}$ \\
\hline & $\operatorname{DFR}(n=30)$ & $0.241 \pm 0.013^{\mathrm{abc}}$ & $0.289 \pm 0.019^{\mathrm{abc}}$ & $0.272 \pm 0.016^{\mathrm{abc}}$ & $0.228 \pm 0.013^{\mathrm{abc}}$ & $0.192 \pm 0.050^{\mathrm{a}}$ \\
\hline
\end{tabular}

a: vs SG at the same altitude, $P<0.05$; b: $v s$ IFR at the same altitude, $P<0.05$; c: $v s$ corresponding group at low altitude, $P<0.05$, Blank means no data.

Table 3. $\mathrm{CD}^{+}$expression in Peyer's patches after burn in rats at two altitudes (A value $\bar{x} \pm \mathrm{s}, \mathrm{n}$ =132).

\begin{tabular}{|c|c|c|c|c|c|c|}
\hline altitude & group & $6 \mathrm{~h} \mathrm{~PB}$ & $12 \mathrm{~h} \mathrm{~PB}$ & $24 \mathrm{~h}$ PB & $48 \mathrm{~h}$ PB & $72 \mathrm{~h}$ PB \\
\hline \multirow{3}{*}{$1517 \mathrm{~m}$} & $S G(n=6)$ & 0.478 & & & & \\
\hline & $\operatorname{IFR}(n=30)$ & $0.327 \pm 0.040^{\mathrm{a}}$ & $0.241 \pm 0.024^{\mathrm{a}}$ & $0.306 \pm 0.020^{\mathrm{a}}$ & $0.312 \pm 0.022^{\mathrm{a}}$ & $0.355 \pm 0.042^{\mathrm{a}}$ \\
\hline & $\operatorname{DFR}(n=30)$ & $0.269 \pm 0.011^{\mathrm{ab}}$ & $0.202 \pm 0.010^{\mathrm{ab}}$ & $0.251 \pm 0.013^{\mathrm{ab}}$ & $0.256 \pm 0.013^{\mathrm{ab}}$ & $0.278 \pm 0.067^{\mathrm{ab}}$ \\
\hline \multirow{3}{*}{$3848 \mathrm{~m}$} & $S G(n=6)$ & $0.376 \pm 0.035$ & & & & \\
\hline & $\operatorname{IFR}(n=30)$ & $0.297 \pm v$ & $0.204 \pm 0.030^{\mathrm{ac}}$ & $0.245 \pm 0.013^{\mathrm{ac}}$ & $0.264 \pm 0.009^{\mathrm{ac}}$ & $0.289 \pm 0.014^{\mathrm{ac}}$ \\
\hline & $\operatorname{DFR}(n=30)$ & $0.228 \pm 0.007^{\mathrm{abc}}$ & $0.145 \pm 0.018^{\mathrm{aBc}}$ & $0.206 \pm 0.006^{\mathrm{abc}}$ & $0.234 \pm 0.009^{\mathrm{abc}}$ & $0.240 \pm 0.010^{\mathrm{abc}}$ \\
\hline
\end{tabular}

a: $v s$ SG at the same altitude, $P<0.05$; b: $v s$ IFR at the same altitude, $P<0.05$;c: $v s$ corresponding group at low altitude, $P<0.05$, Blank means no data.

\section{Discussion}

Immune cells are exposed to different oxygen tension, including hypoxia, as they develop, migrate and function in primary, secondary, and tertiary lymphoid organs with 
different infrastructure, vasculature, and oxygen supply [11] [12]. Hypoxia results in adaptationally appropriate alterations of gene expression through the activation of hypoxia-inducible factor-1 (HIF-1) to overcome any shortage of oxygen. HIF-1 is a basic helix-loop-helix/Per-ARNT-Sim protein consisting of HIF- $1 \alpha$ and HIF- $1 \beta$ subunits. It was shown that the expression of HIF- $1 \alpha$, but not HIF- $1 \beta$, is significantly enhanced by hypoxia [13]-[15]. HIF-1 $\alpha$ expression in T lymphocytes can be induced by hypoxia [16]. T-cell adaptation to hypoxia is characterized by a modulation of cytokine and cell cycle protein expression, associated with an inhibition of T-cell activation and proliferation [17] [18]. Other reports demonstrated that hypoxia induces apoptosis in Jurkat cells, a lymphoblastic cell line [19]. An increase in HIF-1 transcriptional activity enhances apoptosis in thymocytes in vivo in mice that are deficiency in von Hippel Lindau (VHL) protein [20].

Our previous study has demonstrated that the apoptosis rate of gut-associated lymphatic tissue (GALT) increased postburn (PB) with delayed resuscitation [6] [7]. To observe the relationship between HIF- $1 \alpha$ expression and apoptosis and proliferation of lymphocytes in Peyer's patches, animals were subjected to scald burn with delayed resuscitation at $1517 \mathrm{~m}$ and $3848 \mathrm{~m}$ altitude above sea level. In this model, the intestinal lymphocytes of the rats suffered from double hits of hypoxia and ischemia-reperfusion. The results showed that a positive expression of HIF- $1 \alpha$ occurred at $6 \mathrm{~h}$ PB and reached the zenith at $12 \mathrm{~h}$ PB in DFR and IFR group, the expression was obvious especially in DFR group, revealed that a high expression of HIF- $1 \alpha$ in Peyer's patches could be induced by hypoxia and ischemia-reperfusion caused by delayed fluid resuscitation at plateau. The positive expression of HIF- $1 \alpha$ paralleling to the change of apoptosis rate of lymphocytes in Peyer's patches, suggested the involvement of HIF-1 $\alpha$ in the induction of T lymphocyte apoptosis in Peyer's patches.

There was a little expression of HIF- $1 \alpha$ at $3848 \mathrm{~m}$ altitude in sham group; this revealed that hypoxia may be involved in the induction of apoptosis. The result is in agreement with the report that hypoxia could enhance the HIF-1 $\alpha$ accumulation and apoptosis of T cells, and inhibit T-cell proliferation [21].

$\mathrm{CD}^{+}$protein, as a marker of $\mathrm{T}$ lymphocytes, the trough value of $\mathrm{CD}^{+}$expression also appeared at $12 \mathrm{~h} \mathrm{~PB}$, and the value in DFR group were all lower than that in IFR group at different altitude. And the lowest expression of $\mathrm{CD}^{+}$occurred at $12 \mathrm{~h} \mathrm{~PB}$. These results suggested that the apoptotic lymphocytes were mainly $\mathrm{T}$ cells. The expression of $\mathrm{CD}^{+}$protein was antiparalleled to the apoptosis of lymphocytes [6] [7], suggested that the proliferation of lymphocytes in Peyer's patches were decreased after burn and delayed resuscitation at plateau. It was reported that hypoxia could inhibit the proliferation of $\mathrm{T}$ cells [21].

It is well known that hypoxia increase cellular ROS generation, probably from mitochondrial electron transport complexes [22]. It has been demonstrated that Noxa, a member of BH3-only Bcl-2 family proteins, is an HIF- $1 \alpha$-dependent hypoxia-inducible gene and mediates hypoxic cell death in an ROS-dependent manner. Suppression of Noxa expression by antisense oligonucleotides rescued cells from hypoxia-induced cell 
death and decreased infarction volumes in an animal model of ischemia [23]. Therefore, the mechanism which the expression of HIF-1 $\alpha$ promotes the apoptosis of T lymphocytes in Peyer's patches in this model might be related to the production of ROS caused by hypoxia and ischemia-reperfusion due to delayed resuscitation [24].

ROS could stabilize HIF- $1 \alpha$ and prevent the degradation of HIF-1 $\alpha$. The HIF-1 $\alpha$ could be detected in T lymphocytes in sham group, because the half-life of HIF-1 $\alpha$ was very short under normoxia. They were ubiliquitinated quickly after production, and then dissolved by protease [25]-[27]. Therefore, ischemia and hypoxia induced the expression of HIF-1 $\alpha$ after severe scald with delayed resuscitation at high altitude, and aggravated the injury of $\mathrm{T}$ lymphocytes.

\section{Funding}

Supported by: The general program of medical science and technology of Chinese PLA during the 11th "five year" plan. Fund No: (06G030).

\section{References}

[1] Halteman, M.W. and Federoff, H.J. (1999) HIF-l $\alpha$ and p53 Promote Hypoxia-Induced Delayed Death in Models of CNS Ischemia. Experimental Neurology, 159, 65-72. http://dx.doi.org/10.1006/exnr.1999.7160

[2] Bunn, H.F. and Poiton, R.O. (1996) Oxygen Sensing and Molecular Adaptation to Hypoxia. Physiological Reviews, 76, 839-885.

[3] Deindl, E., Buschmann, I., Hoefer, I.E., Podzuweit, T., Boengler, K., Vogel, S., van Royen, N., Fernandez, B. and Schaper, W. (2001) Role of Ischemia and of Hypoxia-Inducible Genes in Arteriogenesis after Femoral Artery Occlusion in the Rabbit. Circulation Research, 89, 779-786. http://dx.doi.org/10.1161/hh2101.098613

[4] Semenza, G.L. and Wang, G.L. (1992) A Nuclear Factor Induced by Hypoxia via de Novo Protein Synthesis Binds to the Human Erythropoietin Gene Enhancer at a Site Required for Transcriptional Activation. Molecular and Cellular Biology, 12, 5447-5454. http://dx.doi.org/10.1128/MCB.12.12.5447

[5] Semenza, G.L. (2000) HIF-1: Mediator of Physiological and Pathophysiological Responses to Hypoxia. Journal of Applied Physiology, 88, 1474-1480.

[6] Zhang, C., Sheng, Z.Y., Lu, Y., Hu, S., Sun, X.Q., Liu, Y. and Zhang, S.F. (2003) Change in Apoptosis Rate and Expression of Apoptosis-Related Gene of Lamina Propria Lymphocyte and Intraepithelial Lymphocyte after Burn and Delayed Resuscitation. Chin Crit care Med, 15, 284-287.

[7] Zhang, C., Liu, Y., Hu, S., Li, J.Y., Lu, Y. and Sun, X.Q. (2008) Influence of Delayed Resuscitation on the Apoptosis of Intestinal Lymphocyte after Scald in Rats. Infection, Inflammation, Repair, 9, 150-152.

[8] Fan, J., Xie, Y., Li, X., Guo, G., Meng, O., Xiu, Y., Li, T., Feng, W. and Ma, L. (2009) The Influence of Peyer's Patch Apoptosis on Intestinal Mucosal Immunity in Burned Mice. Burns, 35, 687-94. http://dx.doi.org/10.1016/j.burns.2008.10.013

[9] Makino, Y., Nakamura, H., Ikeda, E., Ohnuma, K., Yamauchi, K., Yabe, Y., Poellinger, L., Okada, Y., Morimoto, C. and Yanaka, H. (2003) Hypoxia-Inducible Factor Regulates Survival of Antigen Receptor-Driven T Cells. Journal of Immunology, 171, 6534-6540.

[10] Gavrieli, Y., Sheman, Y. and Bensasson, S.A. (1992) Identification of Programmed Death 
via Specific Labeling of Nuclear DNA Fragmentation. The Journal of Cell Biology, 119, 493-501. http://dx.doi.org/10.1083/jcb.119.3.493

[11] Caldwell, C.C., Kojima, H., Lukashev, D., Armstrong, J., Farber, M., Apasov, S.G. and Sitkovsky, M.V. (2001) Dfferential Effects of Physiologically Relevant Hypoxic Conditions on T Lymphocyte Development and Effector Functions. Journal of Immunology, 167, 6140-6149. http://dx.doi.org/10.4049/jimmunol.167.11.6140

[12] Sitkovsky, M. and Lukashev, D. (2005) Regulation of Immune Cells by Local-Tissue Oxygen Tension: HIF-1 $\alpha$ and Adenosine Receptors. Nature Reviews Immunology, 5, 712-721. http://dx.doi.org/10.1038/nri1685

[13] Wang, G.L., Jiang, B.H., Rue, E.A. and Semenza, G.L. (1995) Hypoxia-Inducible Factor 1 Is a Basic-Helix-Loop-Helix-PAS Heterodimer Regulated by Cellular O2 Tension. Proceedings of the National Academy of Sciences of the United States of America, 92, 5510-5514. http://dx.doi.org/10.1073/pnas.92.12.5510

[14] Huang, L.E., Arany, Z., Livingston, D.M. and Bunn, H.F. (1996) Activation of Hypoxia-Inducible Transcription Factor Depends Primarily upon Redox-Sensitive Stabilization of Its Alpha Subunit. Journal of Biological Chemistry, 271, 32253-32259.

[15] Jiang, B.H., Semenza, G.L., Bauer, C. and Marti, H.H. (1996) Hypoxia-Inducible Factor 1 Levels Vary Exponentially over a Physiologically Relevant Range of O2 Tension. American Journal of Physiology, 271, C1172-C1180.

[16] Wang, G.L. and Semenza, G.L. (1993) General Involvement of Hypoxia-Inducible Factor 1 in Transcriptional Response to Hypoxia. Proceedings of the National Academy of Sciences of the United States of America, 90, 4304-4308. http://dx.doi.org/10.1073/pnas.90.9.4304

[17] Naldini, A. and Carraro, F. (1999) Hypoxia Modulates Cyclin and Cytokine Expression and Inhibits Peripheral Mononuclear Cell Proliferation. Journal of Cellular Physiology, 181, 448-454. http://dx.doi.org/10.1002/(SICI)1097-4652(199912)181:3<448::AID-JCP8>3.0.CO;2-F

[18] Naldini, A., Carraro, F., Silvestri, S. and Bocci, V. (1997) Hypoxia Affects Cytokine Production and Proliferative Responses by Human Peripheral Mononuclear Cells. Journal of Cellular Physiology, 173, 335-342. http://dx.doi.org/10.1002/(SICI)1097-4652(199712)173:3<335::AID-JCP5>3.0.CO;2-O

[19] Malhotra, R., Lin, Z., Vincenz, C. and Brosius, F.C. (2001) Hypoxia Induces Apoptosis via Two Independent Pathways in Jurkat Cells: Differential Regulation by Glucose. American Journal of Physiology_Cell Physiology, 281, C1596-C1603.

[20] Biju, M.P., Neumann, A.K., Besinger, S.J., Johnson, R.S., Turka, L.A. and Haase, V.H. (2004) Vhlh Gene Deletion Induces Hif-1-Mediated Cell Death in Thymocytes. Molecular and Cellular Biology, 24, 9038-9047. http://dx.doi.org/10.1128/MCB.24.20.9038-9047.2004

[21] Carraro, F., Pucci, A., Pellegrini, M., Pelicci, P.G., Baldari, C.T. and Naldini, A. (2007) P66Shc Is Involved in Promoting HIF-1Alpha Accumulation and Cell Death in Hypoxic T Cells. Journal of Cellular Physiology, 211, 439-447. http://dx.doi.org/10.1002/jcp.20951

[22] Chuanyu, L. and Robert, M.J. (2002) Reactive Species Mechanisms of Cellular Hypoxia-Reoxygenation Injury. American Journal of Physiology-Cell Physiology, 282, C227C241. http://dx.doi.org/10.1152/ajpcell.00112.2001

[23] Kim, J.Y., Ahn, H.J., Ryu, J.H., Suk, K. and Park, J.H. (2004) BH3-Only Protein NOXA Is a Mediator of Hypoxic Cell Death Induced by Hypoxia-Inducible Factor-l $\alpha$. Journal of Experimental Medicine, 199, 113-124. http://dx.doi.org/10.1084/jem.20030613

[24] Zhang, C., Sheng, Z.Y., Hu, S., Gao, J.C., Li, J.Y., Yu, S. and Liu, Y. (2004) The Role of OFR in the Occurrence of Apoptosis of Enterocytes in Delayed Resuscitation Rats after Scald. 
Trauma, 56, 611-617. http://dx.doi.org/10.1097/01.TA.0000085128.59895.A2

[25] Huang, L.E., Gu, J., Schau, M. and Bunn, H.F. (1998) Regulation of Hypoxia-Inducible Factor $1 \alpha$ Is Mediated by an $\mathrm{O}_{2}$-Dependent Degradation Domain via the Ubiquitin-Proteasome pathway. Proceedings of the National Academy of Sciences of the United States of America, 95, 7987-7992. http://dx.doi.org/10.1073/pnas.95.14.7987

[26] Kallio, P.J., Wilson, W.J., O’Brien, S., Makino, Y. and Poellinger, L. (1999) Regulation of the Hypoxia-Inducible Transcription Factor $1 \alpha$ by the Ubiquitin-Proteasome Pathway. Journal of Biological Chemistry, 274, 6519-6525. http://dx.doi.org/10.1074/jbc.274.10.6519

[27] Salceda, S. and Caro, J. (1997) Hypoxia-Inducible Factor $1 \alpha$ (HIF-1 $\alpha$ ) Protein Is Rapidly Degraded by the Ubiquitin-Proteasome System under Normoxic Conditions. Its Stabilization by Hypoxia Depends on Redox-Induced Changes. Journal of Biological Chemistry, 272, 22642-22647. http://dx.doi.org/10.1074/jbc.272.36.22642

\section{Submit or recommend next manuscript to SCIRP and we will provide best service for you:}

Accepting pre-submission inquiries through Email, Facebook, LinkedIn, Twitter, etc. A wide selection of journals (inclusive of 9 subjects, more than 200 journals)

Providing 24-hour high-quality service

User-friendly online submission system

Fair and swift peer-review system

Efficient typesetting and proofreading procedure

Display of the result of downloads and visits, as well as the number of cited articles

Maximum dissemination of your research work

Submit your manuscript at: http://papersubmission.scirp.org/ 